\title{
Research spending is almost flat for leading Japanese companies
}

Tokyo. The global recession that reached Japan's shores last year is beginning to bite harder into research and development (R\&D) spending by Japan's major industries. A Nature survey of 14 leading electronics and automobile manufacturers that account for 30 per cent of Japan's total industrial research reveals that total R\&D expenditures for the fiscal year ending 31 March will rise barely above last year's level, ending a ten-year period of rapid expansion. In addition, several companies expect to reduce R\&D spending in 1993 for the first time in several decades.

The shift, which has already led companies to recruit fewer young scientists and engineers, has also forced researchers to think more about product development. This restructuring of research goals is likely to be the most important long-term consequence of the recession.

The 14 companies surveyed spent a total of $¥ 3,178$ billion (US $\$ 27$ billion) on R\&D in 1991. Projections for fiscal year 1992 (ending $31 \mathrm{March}$ ) show an increase of only 1.5 per cent, with one company - Oki Electric Industry - in which R\&D spending dropped from $¥ 44.4$ billion in 1990 to $¥ 40.9$ billion in 1991 declining to provide figures for 1992 .

Prospects for the coming year appear to be no brighter, with several companies looking at flat or declining R\&D budgets in the fiscal year that starts on 1 April. Hitachi, with the largest R\&D budget of the companies surveyed, expects spending to fall by 4 per cent, from $¥ 520$ billion to $¥ 500$ billion. One of the smaller companies, Sanyo, forecasts a drop from $¥ 85$ billion in 1992 to $¥ 61$ billion in fiscal year 1993 , which for Sanyo ends on 30 November, and Kyocera, the world's leading manufacturer of ceramic packages for integrated circuits, expects a decline of 17 per cent in fiscal 1993.

Toshiba expects its budget to be "about the same or slightly less" in 1993 after a drop of 2.5 per cent in 1992, while NEC expects its R\&D budget to be flat. Two leading car manufacturers, Nissan and Mazda, spent slightly less on R\&D in 1992 than in 1991.

A Toshiba researcher says that the situa-

tion "is not desperate" but that travel to conferences overseas has been "severely cut" and is restricted to reasons related to product development or patents. The company for a time switched off the lighting in

simply be offering management the chance to implement them.

Toshiba has consolidated its laboratories at an R\&D centre in Kawasaki near Tokyo, with some to be reassigned to product development centres. Researchers also are being asked to siphon off ideas that could quickly lead to new products. Again, the recession seems to have provided an excuse to implement plans already in the works.

The changes seem less dramatic at NEC, although basic researchers are being encouraged to explain the potential long-term applications of their work and to transfer to product development centres any ideas that have immediate potential application. Furthermore, they are being asked to discuss with applied researchers the likely direction of future tech-

its laboratories during the lunch period to drive home the message that sacrifices are necessary, although the surge in electricity when the lights go back on actually increased consumption. Nevertheless, it had an important "psychological effect" on researchers, who are looking more closely at proposals and trying wherever possible to cut costs.

Recruitment is also suffering, with Fujitsu announcing last week that it will recruit only 300 engineers in the coming fiscal year compared with 2,200 in 1992 . NEC expects a drop of 10 per cent, from 990 to 900 , and Hitachi expects overall recruitment, including high school graduates, to drop from 4,000 to 2,500 .

More important than these cutbacks, which are likely to be temporary, are moves by top management to restructure the way in which research is carried out and funded. Before the recession, for example, the main corporate research laboratories at Sony were funded by headquarters. Now researchers are being asked to get a large percentage of their research budgets from the 24 business groups that make up Sony.

These business groups operate as independent companies and look for research that is product-orientated. As a result, Sony researchers will have to define more clearly the goals and nature of their work. Such plans were already afoot before the recession, and the freeze on R\&D spending may nologies. The words "strategy and priority" are being used much more today than a few years ago when funds were plentiful, says the head of one of NEC's basic research laboratories. David Swinbanks

\section{Babbitt moves ahead on biological survey}

Washington. In the first step towards creating a new National Biological Survey to consolidate ecological research within his agency, Bruce Babbitt, US interior secretary, has asked the US National Academy of Sciences to advise him on how to organize the new survey (see Nature 361, 574; 1993).

Peter Raven, home secretary of the academy and director of the Missouri Botanical Garden in St Louis, will chair the committee, which is expected to complete its work within six months. Babbitt has asked biologist Thomas Lovejoy of the Smithsonian Institution to join the department on a temporary basis to set up the new survey, which would monitor and inventory species and ecosystems within the United States. The new office wiil have a budget of $\$ 12$ million, and Lovejoy will also serve as acting science adviser to Babbitt.

Tony Reichhardt 